\title{
Dependence of reactions of the external respiratory system in athletes on the orientation of the training process
}

\author{
S. M. Kanyhina $\left(\mathbb{D} * A, B, D, F\right.$, M. S. Potapenko ${ }^{C, D, E}$, L. O. Kurilets ${ }^{\mathrm{C}, \mathrm{D}, \mathrm{E}}$ \\ Zaporizhzhia State Medical University, Ukraine
}

A - research concept and design; B - collection and/or assembly of data; C - data analysis and interpretation; D - writing the article;

$\mathrm{E}$ - critical revision of the article; $\mathrm{F}$ - final approval of the article

Issues of improving the functional training (different orientation of the training process) of athletes due the development of the respiratory system, including the respiratory system, as well as increasing the body's resistance to hypoxic stress remain extremely relevant at the present stage of sport development.

The aim of the study is to investigate the peculiarities of the reaction of the external respiratory system in athletes, depending on the orientation of the training process.

Materials and methods. The study involved 104 athletes ( 84 men and 20 women) skill level from CMS to IMS: 63 -athletes, who developed mainly endurance quality (triathletes, swimmers, long-distance runners, rowing), 31 - strength quality (weightlifters, powerlifting, weightlifting), 10 - speed quality (runners sprinters). The mean age of the athletes under study was $21.75 \pm 3.32$ years. Among them there are international masters of sports (IMS) -2 athletes, masters of sports (MS) -25 , candidates for master of sports -48 , athletes of 1 degree -29 . Computer spirometric examination was performed for all athletes using the spirographic complex "Spirocom" produced by LLC "KHAI-Medica" in Kharkiv in accordance with existing recommendations.

Research results. Analysis of computer spirometry showed, that athletes, who developed the quality of strength had $18.2 \%$ $(P=0.014)$ greater vital capacity of the lungs, due to the predominance of respiratory volume by $29.9 \%(P=0.017)$ and by $42.1 \%(P=0.001)$ inspiratory reserve volume, but less by $22.4 \%(P=0.019)$ expiratory reserve volume, than athletes, who improved the quality of endurance. Athletes, who developed the quality of endurance in contrast to athletes, who improved the quality of speed had a higher forced vital capacity of the lungs by $14.9 \%(P=0.031)$, due to the predominance of a inspiratory reserve volume by $9.8 \%(P=0.049)$ and expiratory reserve volume by $28.5 \%(P=0.044)$. Athletes, who improved the quality of speed had lower vital capacity of the lungs by $26.1 \%(P=0.003)$, forced vital capacity of the lungs by $20.2 \%(P=0.016)$, due to a decrease of inspiratory reserve volume by $34.2 \%(P=0.008)$, than athletes, who improved the quality of strength. Athletes, who developed the quality of speed, had greater resistance to air flow in the bronchi of small caliber in the exhalation phase, as evidenced by a lower rate of forced expiratory volume, by $21.1 \%(P=0.015)$, the volume of forced expiratory to reach the peak expiratory flow by $30.2 \%(P=0.016)$, MEF 75 by $22.9 \%(P=0.036)$, FEF $75-85$ by $22.8 \%(P=0.035)$, than athletes, who developed the quality of strength.

Conclusions Athletes, who have developed a quality of strength have a greater vital capacity of the lungs, due to the predominance of respiratory volume and inspiratory reserve volume, but less expiratory reserve volume, than in athletes, who improved the quality of endurance. Athletes, who developed endurance quality, in contrast to athletes, who improved the quality of speed, have a higher forced vital capacity of the lungs, due to the predominance of inspiratory and expiratory reserve volumes. The function of external respiration of athletes, who improved the quality of speed is characterized by lower vital capacity of the lungs, forced vital capacity of the lungs, due to reduced inspiratory reserve volume, and greater resistance to airflow in the bronchi of small caliber in the expiratory phase, than in athletes, who developed the quality of strength.

\section{Залежність реакцій системи зовнішнього дихання у спортсменів від спрямованості тренувального процесу}

\section{С. М. Канигіна, М. С. Потапенко, А. О. Курілець}

Питання підвищення функціональної підготовки (різної спрямованості тренувального процесу) спортсменів шляхом розвитку респіраторної системи, зокрема системи зовнішнього дихання, а також підвищення стійкості організму до гіпоксичного навантаження залишаються надзвичайно актуальними на сучасному етапі розвитку спорту.

Мета роботи - вивчити особливості реакції системи зовнішнього дихання у спортсменів залежно від спрямованості тренувального процесу.

Матеріали та методи. У дослідження залучили 104 спортсменів (84 чоловіки і 20 жінок): 63 атлети, які розвивали переважно якість витривалості, 31 - якість сили, 10 - якість швидкості. Середній вік обстежених становив 21,75 $\pm 3,32$ року. Серед обстежених - 2 майстри спорту міжнародного класу (МСМК), 25 майстрів спорту (МС), 48 кандидатів у майстри спорту, 29 спортсменів 1 розряду. Комп'ютерне спірометричне дослідження виконали всім спортсменам на спірографрічному комплексі «Спіроком» (ТОВ «ХАІ-Медіка», м. Харків) відповідно до рекомендацій.

Результати. Аналіз показників комп'ютерної спірометрії встановив, що у спортсменів, які розвивали якість сили, на 18,2 ( $p=0,014)$ більша життєва ємність легень унаслідок переважання на 29,9 \% ( $p=0,017)$ дихального об'єму та на 42,1 \% ( $p=0,001)$ резервного об'єму вдиху, але менший на 22,4 \% ( $p=0,019)$ резервний об'єм видиху, ніж у спортсменів,
Key words: athletes, respiration, physical endurance, strength, speed.

Pathologia 2021; 18 (1), 103-111

*E-mail: malakhova sn@ukr.net

Ключові слова: спортсмени, функція зовнішнього Аихання, витривалість, сила, швиАКість.

Патологія. 2021. T. 18, № 1(51).

C. $103-111$ 
які удосконалювали якість витривалості. Спортсмени, які розвивали якість витривалості, на відміну від спортсменів, які удосконалювали якість швидкості, мали більшу форсовану життєву ємність легень на $14,9 \%$ ( $p=0,031)$ через переважання резервного об'єму вдиху на 9,8 \% ( $p=0,049)$ та резервного об'єму видиху на $28,5 \%$ ( $=0,044)$. Спортсмени, які удосконалювали якість швидкості, мали меншу життєву ємність легень на 26,1 \% ( $p=0,003)$, форсовану життєву ємність легень на 20,2 \% ( $p=0,016)$ унаслідок зниження на 34,2 \% ( $p=0,008)$ резервного об'єму вдиху, ніж атлети, які удосконалювали якість сили. Спортсмени, які розвивали якість швидкості, мали більший опір повітряному потоку у бронхах малого калібру у фазу видиху, про що свідчать менші на $21,1 \%$ ( $p=0,015)$ показник об'єму форсованого видиху $30,2 \%(p=0,016)$ об'єму форсованого видиху до досягнення пікової об'ємної швидкості, на 22,9% ( $p=0,036)$ МОШ 75 , на 22,8 \% ( $p=0,035)$ СОШ 75-85, ніж у спортсменів, які розвивали якість сили.

Висновки. Спортсменам, які розвивали якість сили, притаманна більша життєва ємність легень через переважання дихального об'єму та резервного об'єму вдиху, але менший резервний об'єм видиху порівняно зі спортсменами, які удосконалювали якість витривалості. У спортсменів, які розвивали якість витривалості, на відміну від спортсменів, які удосконалювали якість швидкості, визначена більша фрорсована життєва ємність легень унаслідок переважання резервних об'ємів вдиху та видиху. Функція зовнішнього дихання спортсменів, які удосконалювали якість швидкості, характеризується меншою життєвою ємністю легень, форсованою життєвою ємністю легень через зниження резервного об'єму вдиху, більшим опором повітряному потоку у бронхах малого калібру у фазу видиху, ніж в атлетів, які розвивали якість сили.

Киючевые слова: спортсмены, функция внешнего Аыхания, выносливость, сила, скорость.

Патология. 2021. T. 18, № 1(51).

C. 103-111

\section{Зависимость реакций системы внешнего дыхания у спортсменов от направленности тренировочного процесса}

\section{С. Н. Каныгина, М. С. Потапенко, А. О. Курилец}

Вопросы повышения функциональной подготовки (различной направленности тренировочного процесса) спортсменов за счет развития респираторной системы, в том числе системы внешнего дыхания, а также повышения устойчивости организма к гипоксическим нагрузкам остаются чрезвычайно актуальными на современном этапе развития спорта.

Цель работы - изучить особенности реакции системы внешнего дыхания у спортсменов в зависимости от направленности тренировочного процесса.

Материалы и методы. Обследовали 104 спортсмена (84 мужчины и 20 женщин): 63 атлета, которые развивали преимущественно качество выносливости, 31 -качество силы, 10 -качество скорости. Средний возраст обследованных 21,75 \pm 3,32 года. Среди них - 2 мастера спорта международного класса (МСМК), 25 мастеров спорта (МС), 48 кандидатов в мастера спорта, 29 спортсменов 1 разряда. Компьютерное спирометрическое исследование проведено всем спортсменам на спирографическом комплексе «Спироком» (ООО «ХАИ-Медика, г. ХарькОв) в соответствии с рекомендациями.

Результаты. Анализ показателей компьютерной спирометрии установил, что у спортсменов, развивающих качество силы, на 18,2 \% ( $p=0,014)$ больше жизненная емкость легких за счет преобладания на $29,9 \%$ ( $p=0,017)$ дыхательного объема и на 42,1 \% ( $p=0,001)$ резервного объема вдоха, но меньше на 22,4 \% ( $p=0,019)$ резервный объем выдоха, чем у спортсменов, которые совершенствовали качество выносливости. Спортсмены, развивающие качество выносливости, в отличие от спортсменов, совершенствующих качество скорости, имели большую форсированную жизненную емкость легких на $14,9 \%(p=0,031)$ за счет преобладания как резервного объема вдоха на $9,8 \%(p=0,049)$, так и резервного объема выдоха на $28,5 \%$ ( $p=0,044)$. Спортсмены, которые совершенствовали качество скорости, имели меньшую жизненную емкость легких на 26,1 \% ( $p=0,003)$, форсированную жизненную емкость легких на 20,2 \% ( $p=0,016)$ за счет снижения на $34,2 \%$ ( $p=0,008$ ) резервного объема вдоха, чем атлеты, которые совершенствовали качество силы. Спортсмены, развивающие качество скорости, имели большее сопротивление воздушному потоку в бронхах малого калибра в фазу выдоха, о чем свидетельствуют меньшие на 21,1 \% ( $p=0,015$ ) показатель объема фрорсированного выдоха 1 , на 30,2 \% ( $p=0,016)$ объема форсированного выдоха до достижения пиковой объемной скорости, на 22,9\% ( $p=0,036)$ MOC 75, на 22,8 \% ( $p=0,035)$ COC 75-85, чем у спортсменов, развивающих качество силы.

Выводы. Спортсменам, которые развивали качество силы, присуща большая жизненная емкость легких за счет преобладания дыхательного объема и резервного объема вдоха, но меньший резервный объем выдоха по сравнению со спортсменами, совершенствующими качество выносливости. У спортсменов, которые развивали качество выносливости, в отличие от спортсменов, совершенствовавших качество скорости, отмечена большая форсированная жизненная емкость легких за счет преобладания резервных объемов вдоха и выдоха. Функция внешнего дыхания спортсменов, которые совершенствовали качество скорости, характеризуется меньшей жизненной емкостью легких, форсированной жизненной емкостью легких за счет снижения резервного объема вдоха, большим сопротивлением воздушному потоку в бронхах малого калибра в фазу выдоха, чем у атлетов, которые развивали качество силы.

Achieving high sports results is based on improvement and maximum implementation of the functional abilities of the athlete in the process of competitive activity [8]. In the process of adaptation, associated with long-term sports training, optimization of the physiological reactivity of the cardio-respiratory system is achieved, the nature of which is directly related to the individual characteristics of athletes, periods and orientation of the training process [11]. In the dynamics of various physical or combined loads, the reserves of the functional system of external respiration can be significantly reduced until they are completely exhausted. A set of indicators of external respiration can be a marker of the adaptive potential of a person of different ages [5]. One of the most important indicators of sports performance is the functional state of the external respiratory system. In this regard, the interest of scientists in improving the functional training of athletes through the development of the respiratory system, including 
Table 1. Anthropometric data of athletes who developed the qualities of endurance, strength or speed, $M \pm S D$

\begin{tabular}{l|l|l|l|l|l}
\hline Value, units of measure & Endurance & Strength & Speed & $\mathbf{P}_{1 \cdot 2}$ & $\mathbf{P}_{1 \cdot 3}$ \\
Age, years & $21.22 \pm 3.16$ & $22.42 \pm 3.56$ & $23.00 \pm 3.13$ & 0.099 & 0.114 \\
Height, $\mathrm{m}$ & $1.78 \pm 0.08$ & $1.78 \pm 0.10$ & $1.71 \pm 0.10$ & 0.777 & 0.028 \\
Weight, $\mathrm{kg}$ & $66.79 \pm 9.42$ & $82.13 \pm 19.03$ & $63.50 \pm 15.99$ & 0.059 & 0.001 \\
BMl, $\mathrm{kg} / \mathrm{m}^{2}$ & $20.93 \pm 1.69$ & $25.78 \pm 4.26$ & $21.34 \pm 3.24$ & 0.478 & 0.001 \\
\hline
\end{tabular}

the external respiratory system, as well as increasing the body's resistance to hypoxic stress has always been great in the past and continues to grow now [4].

\section{Aim}

The purpose of the study is to investigate the peculiarities of the reaction of the external respiratory system in athletes depending on the orientation of the training process.

\section{Materials and methods}

After signing a written informed consent, in the competitive period, study involved 104 athletes (84 men and 20 women) skill level from CMS to IMS: 63 - athletes, who developed mainly endurance quality (triathletes, swimmers, long-distance runners, rowing), 31 - strength quality (weightlifters, powerlifting, weightlifting), 10 - speed quality (runners sprinters). The mean age of the athletes under study was $21.75 \pm 3.32$ years. Among them are international masters of sports (IMS) -2 athletes, masters of sports (MS) -25 , candidates for master of sports -48 , athletes of 1 degree -29 .

Computer spirometric examination was performed for all athletes using the spirographic complex "Spirocom" produced by LLC "KHAI-Medica" in Kharkiv in accordance with existing recommendations [9]. In the conditions of maximum physical loadings in an annual cycle vital capacity of lungs (VC, I), the forced vital capacity of lungs $(F V C, I)$, volume of the forced expiratory volume in 1 second (FEV1, I), inspiratory reserve volume (IRV), expiratory reserve volume (ERV), respiratory volume (RV, $\mathrm{I})$, respiration rate $(R R)$, low voluntary ventilation (LVV), the ratio of inspiratory duration/expiratory duration $\left(D_{\text {insp }}\right.$ l $\mathrm{D}_{\text {exp }}$ ), maximal voluntary ventilation (MVV), mean forced expiratory flow between 25 and $75 \%$ FVC (FEF 25-75, $\mathrm{l} / \mathrm{s}$ ), mean forced expiratory flow between 75 and $85 \%$ of FVC (FEF 75-85, I/s), speed of expiratory air stream peak expiratory flow (PEF), time for peak expiratory flow (Tpef, s), maximal expiratory flow at $25 \%$ of volume of the forced exhalation (MEF 25, I/s), maximal expiratory flow at $50 \%$ of the forced expiratory volume (MEF 50, l/s), maximal expiratory flow at $75 \%$ of the forced expiratory volume (MEF 75, l/s), maximal expiratory flow at $85 \%$ of the volume of forced exhalation (MEF $85, \mathrm{l} / \mathrm{s}$ ), Tiffeneau index $(\mathrm{TI})$ were measured.

The results were processed by methods of variation statistics, using the software package Statistica for Windows 13 (StatSoft Inc., № JPZ804I382130ARCN10-J). The hypothesis of the distribution of quantitative indicators, which corresponds to the normal law, was tested using the Shapiro-Wilk test.

Quantitative indicators are presented in the form of arithmetic mean and standard deviation in the case of normal growth and in the view of the median and inter- quartile range in the view of the rise in the normal range, qualitative indicators - in the form of absolute and relative frequencies. Comparison of quantitative indicators in independent groups was determined by the method of parametric statistics using a two-sample Student's t-test with a two-sided test index for the value of statistical significance. In the case of deviation of the distribution from normal, the Mann-Whitney test was used. The difference in qualitative characteristics in independent groups was assessed using Pearson's chi-square test with Yates correction and Fisher's exact criterion. The differences were considered significant at the level of statistical significance $P<0.05$.

\section{Results}

Anthropometric data of athletes are shown in Table 1.

Athletes were comparable in age (Table 1). Athletes, who developed speed quality had significantly lower stature, than strength athletes and athletes, who improved endurance quality. Weightlifters also had significantly more body weight and body mass index, than athletes, who developed endurance or speed qualities.

Comparison of indicators of the function of external respiration in athletes, who developed the qualities of endurance or strength indicates the predominance of athletes, who improved the quality of endurance indicators (Table 2): $D_{\text {insp }} / D_{\text {exp }}(0.94 \pm 0.37$ vs. $0.78 \pm 0.27$ l) by $17.0 \%(P=0.021)$, ERV $(1.65 \pm 0.94$ vs. $1.28 \pm 0.55)$ by $22.4 \%(P=0.019)$, the ratio of the forced inspiratory volume in 2 second to the forced vital capacity of the lungs (FIV2/FVC) $(99.55 \pm 1.11$ vs. $98.98 \pm 2.16 \mathrm{I})$ by $1.0 \%$ $(P=0.025)$.

Table 2. Indicators of the external respiration function in athletes, who developed the quality of endurance or strength, $M \pm S D, M e\left(Q_{25} ; Q_{75}\right)$

\begin{tabular}{|c|c|c|c|c|}
\hline \multirow{2}{*}{$\begin{array}{l}\text { Value, } \\
\text { units of measure }\end{array}$} & \multicolumn{2}{|l|}{ Quality } & \multirow[t]{2}{*}{ P-level } & \multirow[t]{2}{*}{$\Delta \%$} \\
\hline & Endurance $(n=54)$ & Strength $(n=31)$ & & \\
\hline $\mathrm{RV}, \mathrm{I}$ & $0.69(0.53 ; 0.91)$ & $0.92(0.63 ; 1.34)$ & 0.017 & $29.9 \%$ \\
\hline $\mathrm{RV}, \%$ & $93(73 ; 126)$ & $103(82 ; 156)$ & 0.123 & \\
\hline LVV, I & $13.29 \pm 4.93$ & $15.15 \pm 4.83$ & 0.056 & \\
\hline LVV, \% & $102.52 \pm 36.93$ & $111.16 \pm 40.31$ & 0.347 & \\
\hline $\mathrm{RR}, \mathrm{I} / \mathrm{min}$ & $17.72 \pm 4.92$ & $16.70 \pm 5.28$ & 0.371 & \\
\hline$D_{\text {insp }}, s$ & $1.72 \pm 0.59$ & $1.66 \pm 0.52$ & 0.837 & \\
\hline$D_{\text {exp }}, s$ & $1.92 \pm 0.69$ & $2.31 \pm 0.97$ & 0.085 & \\
\hline$D_{\text {insp }} / D_{\text {exp }}$ & $0.94 \pm 0.37$ & $0.78 \pm 0.27$ & 0.021 & $17.0 \%$ \\
\hline $\mathrm{RVm}, \mathrm{I}$ & $1.19 \pm 0.56$ & $1.23 \pm 0.58$ & 0.875 & \\
\hline $\mathrm{RRm}, \mathrm{I} / \mathrm{min}$ & $113.34 \pm 41.77$ & $109.19 \pm 35.10$ & 0.878 & \\
\hline $\mathrm{MVV}, \mathrm{I} / \mathrm{min}$ & $117.97 \pm 36.59$ & $120.36 \pm 39.98$ & 0.912 & \\
\hline MVV, \% & $91.37 \pm 25.52$ & $86.65 \pm 21.56$ & 0.358 & \\
\hline VC, I & $4.61 \pm 1.29$ & $5.45 \pm 1.31$ & 0.014 & $18.2 \%$ \\
\hline VC, \% & $89.70 \pm 23.35$ & $99.14 \pm 20.94$ & 0.061 & \\
\hline IRV, I & $2.14 \pm 0.86$ & $3.04 \pm 1.15$ & 0.001 & $42.1 \%$ \\
\hline ERV, I & $1.65 \pm 0.94$ & $1.28 \pm 0.55$ & 0.019 & $22.4 \%$ \\
\hline
\end{tabular}


Cont. of Table 2.

\begin{tabular}{|c|c|c|c|c|}
\hline \multirow{2}{*}{$\begin{array}{l}\text { Value, } \\
\text { units of measure }\end{array}$} & \multicolumn{2}{|l|}{ Quality } & \multirow[t]{2}{*}{ P-level } & \multirow[t]{2}{*}{$\Delta \%$} \\
\hline & Endurance $(n=54)$ & Strength $(n=31)$ & & \\
\hline FVC, I & $4.83 \pm 1.12$ & $5.15 \pm 1.17$ & 0.201 & \\
\hline FVC, $\%$ & $92.34 \pm 15.93$ & $95.84 \pm 17.69$ & 0.408 & \\
\hline FEV1, I & $4.50 \pm 1.00$ & $4.92 \pm 1.23$ & 0.196 & \\
\hline FEV1, \% & $94.52 \pm 21.86$ & $99.26 \pm 18.84$ & 0.401 & \\
\hline FEVpef, I & $2.47 \pm 0.97$ & $2.85 \pm 1.17$ & 0.157 & \\
\hline FEVpef, \% & $102.98 \pm 37.57$ & $118.32 \pm 47.64$ & 0.196 & \\
\hline IT, $\%$, value & $97.60(86.15 ; 111.50)$ & $94.50(83.30 ; 101.10)$ & 0.401 & \\
\hline IT, \% & $108.50(55.50 ; 124.50)$ & $105.00(93.00 ; 112.00)$ & 0.408 & \\
\hline FEV1/FVC, \%, value & $95.36 \pm 8.05$ & $95.46 \pm 7.49$ & 0.815 & \\
\hline FEV1/FVC, $\%$ & $103.81 \pm 8.85$ & $103.90 \pm 8.32$ & 0.792 & \\
\hline PEF, l/s & $-5.93 \pm 1.73$ & $-6.63 \pm 2.14$ & 0.174 & \\
\hline PEF, \% & $74.30 \pm 20.14$ & $79.29 \pm 20.62$ & 0.333 & \\
\hline MEF $25,1 / s$ & $-4.91 \pm 1.84$ & $-5.59 \pm 2.07$ & 0.211 & \\
\hline MEF $25, \%$ & $67.48 \pm 24.79$ & $72.29 \pm 21.48$ & 0.371 & \\
\hline MEF $50,1 / \mathrm{s}$ & $-5.62 \pm 1.62$ & $-6.22 \pm 1.98$ & 0.181 & \\
\hline MEF $50, \%$ & $70.72 \pm 18.73$ & $74.94 \pm 18.68$ & 0.285 & \\
\hline MEF 75, I/s & $-5.33 \pm 1.78$ & $-5.93 \pm 2.02$ & 0.290 & \\
\hline MEF $75, \%$ & $80.06 \pm 22.89$ & $90.84 \pm 27.56$ & 0.119 & \\
\hline FEF $25-75,1 / \mathrm{s}$ & $-5.41 \pm 1.60$ & $-6.06 \pm 2.03$ & 0.186 & \\
\hline FEF $75-85,1 / s$ & $-5.03 \pm 1.57$ & $-5.53 \pm 1.94$ & 0.391 & \\
\hline Tpef, s & $0.44 \pm 0.19$ & $0.46 \pm 0.20$ & 0.798 & \\
\hline VC, I & $4.84 \pm 1.07$ & $5.20 \pm 1.02$ & 0.155 & \\
\hline VC, \% & $94.48 \pm 14.60$ & $95.23 \pm 11.17$ & 0.724 & \\
\hline IRV, I & $2.66 \pm 1.12$ & $3.43 \pm 1.30$ & 0.015 & $28.9 \%$ \\
\hline ERV, I & $1.35 \pm 1.08$ & $0.79 \pm 0.82$ & 0.074 & \\
\hline FVC, I & $4.71 \pm 0.99$ & $4.95 \pm 0.98$ & 0.295 & \\
\hline FVC, $\%$ & $91.62 \pm 12.30$ & $91.81 \pm 9.95$ & 0.795 & \\
\hline FEV0,5, I & $2.90 \pm 0.63$ & $2.97 \pm 0.66$ & 0.646 & \\
\hline FEV1, I & $4.26 \pm 0.85$ & $4.37 \pm 0.83$ & 0.714 & \\
\hline FEV1, \% & $98.51 \pm 17.60$ & $99.45 \pm 11.89$ & 0.853 & \\
\hline FEV2, I & $4.80(3.94 ; 5.36)$ & $4.88(4.29 ; 5.60)$ & 0.429 & \\
\hline FEV2, \% & $96.33 \pm 24.91$ & $94.62 \pm 9.04$ & 0.073 & \\
\hline FEV3, I & $5.72(4.71 ; 6.29)$ & $5.34(4.51 ; 6.14)$ & 0.405 & \\
\hline FEV3, \% & $88.69 \pm 42.91$ & $91.34 \pm 7.18$ & 0.101 & \\
\hline FEVpef, I & $1.12 \pm 0.42$ & $1.14 \pm 0.49$ & 0.924 & \\
\hline FEVpef, \% & $109.78 \pm 42.15$ & $108.92 \pm 50.48$ & 0.652 & \\
\hline IT & $91.86(81.30 ; 107.00)$ & $81.70(73.30 ; 93.50)$ & 0.375 & \\
\hline IT, $\%$, value & $89.79 \pm 12.61$ & $84.41 \pm 13.29$ & 0.172 & \\
\hline IT, \% & $107.24 \pm 12.83$ & $105.53 \pm 15.80$ & 0.694 & \\
\hline FIV1/FVC, $\%$, value & $91.03 \pm 7.91$ & $88.80 \pm 9.76$ & 0.299 & \\
\hline FIV1/FVC, \% & $110.15 \pm 9.81$ & $109.62 \pm 11.73$ & 0.970 & \\
\hline FIV2/FVC, $\%$, value & $99.55 \pm 1.11$ & $98.98 \pm 2.16$ & 0.025 & $0.6 \%$ \\
\hline FIV2/ FVC, \% & $105.29 \pm 1.36$ & $104.72 \pm 2.64$ & 0.520 & \\
\hline FIV3/FVC, $\%$, value & $100.00 \pm 0.20$ & $99.89 \pm 0.29$ & 0.236 & \\
\hline FIV3/FVC, \% & $103.00 \pm 0.20$ & $102.91 \pm 0.30$ & 0.685 & \\
\hline PEF/FEVpef, I/s & $6.15(4.48 ; 8.83)$ & $6.87(4.05 ; 10.20)$ & 0.425 & \\
\hline FEVpef, I/s & $6.75 \pm 1.71$ & $7.09 \pm 2.22$ & 0.425 & \\
\hline FEVpef, \% & $75.64 \pm 17.67$ & $75.32 \pm 18.82$ & 0.276 & \\
\hline MEF $25,1 / s$ & $6.33 \pm 1.61$ & $6.49 \pm 2.09$ & 0.884 & \\
\hline MEF $25, \%$ & $78.08 \pm 18.71$ & $75.71 \pm 20.38$ & 0.393 & \\
\hline MEF $50,1 / \mathrm{s}$ & $5.20 \pm 1.27$ & $5.36 \pm 1.25$ & 0.276 & \\
\hline MEF $50, \%$ & $98.36 \pm 20.89$ & $97.88 \pm 19.69$ & 0.745 & \\
\hline MEF 75, I/s & $3.37 \pm 1.02$ & $3.32 \pm 0.93$ & 0.745 & \\
\hline MEF $75, \%$ & $125.55 \pm 33.34$ & $128.39 \pm 33.22$ & 0.928 & \\
\hline FEF $0.2-1.2,1 / \mathrm{s}$ & $4.35 \pm 2.09$ & $4.60 \pm 2.63$ & 0.537 & \\
\hline FEF $25-75, \mathrm{l} / \mathrm{s}$ & $4.81 \pm 1.15$ & $4.94 \pm 1.14$ & 0.012 & $2.7 \%$ \\
\hline FEF $25-75, \%$ & $101.27 \pm 25.85$ & $102.29 \pm 20.22$ & 0.574 & \\
\hline FEF $75-85,1 / s$ & $2.94 \pm 0.95$ & $2.83 \pm 0.86$ & 0.884 & \\
\hline FEF $75-85, \%$ & $138.66 \pm 40.13$ & $141.97 \pm 38.03$ & 0.745 & \\
\hline
\end{tabular}

At the same time, athletes who developed the qualities of endurance or strength, probably differed in the volume of respiratory volume (RV) $(0.77 \pm 0.34$ vs. $1.00 \pm 0.44 \mathrm{I})$ by $29.9 \%(\mathrm{P}=0.017), \mathrm{VCL}(4.61 \pm 1.29$ vs. $5.45 \pm 1.31 \mathrm{I})$ by $18.2 \%(P=0.014)$, the reserve volume of inspiration $(\mathrm{RVI})(2.14 \pm 0.86 \mathrm{vs} .3 .041 .15 \mathrm{I})$ at $42.1 \%(P=0.001), \operatorname{IRV}(2.66 \pm 1.12$ vs. $3.43 \pm 1.30 \mathrm{I})$ at $(P=0.015))$ by $28.9 \%$, FEF 25-75 (4.81 \pm 1.15 vs. $4.94 \pm 1.14 \mathrm{l} / \mathrm{s})$ by $2.7 \%(P=0.012)$ in favor of athletes, who developed strength.

Athletes, who developed strength quality also had slightly better rates of LVV $(P=0.056), D_{\text {exp }}(P=0.085)$, VC,\% ( $P=0.061)$, compared to athletes, who developed the quality of endurance, but hardly probable.

Thus, athletes, who developed strength quality had $18.2 \%(P=0.014)$ greater vital capacity, due to the predominance of $29.9 \%(P=0.017)$ respiratory volume and $42.1 \%(P=0.001)$ inspiratory reserve volume, than athletes, who improved the quality of endurance. At the same time, the latter, in contrast to strength athletes, had a greater expiratory reserve volume by $22.4 \%$ $(P=0.019)$.

Analysis of the comparison of indicators of the function of external respiration in athletes, who developed the qualities of speed or endurance (Table 3) found a probably significant predominance of the values of following indicators in the latter: $\operatorname{ERV}(1.65 \pm 0.94$ vs. $1.18 \pm 0.41 \mathrm{I})$ on $28.5 \%(P=0.044), F V C(4.83 \pm 1.12$ vs. $4.11 \pm 1.19$ I $)$ by $14.9 \%(P=0.031)$, IRV $(2.66 \pm 1.12$ vs. $2.40 \pm 0.96 \mathrm{I})$ by $9.8 \%(\mathrm{P}=0.049), \mathrm{FVC}(4.71 \pm 0.99$ vs. $4.20 \pm 1.21)$ by $10.8 \%(P=0.037)$, forced inhalation1 to forced vital capacity of the lungs (FIV1/ FVC) $(91.03 \pm 7.91$ vs. $88.94 \pm 10.62)$ by $2.3 \%$ $(P=0.010)$.

Rather better indicators of VC $(P=0.094)$, FEV1 $(P=0.069)$, FEVpef $(P=0.025), \operatorname{MEF} 75(P=0.080)$, FEF 75-85 ( $P=0.060)$ in athletes, who developed endurance compared to speed, but the difference did not reach the limit of statistical significance.

Thus, athletes who developed the quality of endurance in contrast to athletes, who improved the quality of speed, had a higher forced vital capacity of the lungs by $14.9 \%(P=0.031)$, due to the predominance of both the inspiratory reserve volume by $9.8 \%(P=0.049)$ and expiratory reserve volume by $28.5 \%(P=0.044)$.

Comparison of indicators of the external respiration function in athletes, who developed the qualities of strength or speed (Table 4) proves, that strength athletes have probably higher indicators of VC by $26.1 \%$ $(5.45 \pm 1.31$ vs. $4.03 \pm 0.92 \mathrm{I}, \mathrm{P}=0.003)$, IRV by $34.2 \%$ (3.04 \pm 1.15 vs. $2.00 \pm 0.80 \mathrm{l}, \mathrm{P}=0.008)$, FVC by $20.2 \%(5.15 \pm 1.17$ vs. $4.11 \pm 1.19 \mathrm{I}, \mathrm{P}=0.016)$, FEV1 by $21.1 \%(4.92 \pm 1.23$ vs. $3.88 \pm 1.06$ l, $\mathrm{P}=0.015)$, FEVpef by $30.2 \%(2.85 \pm 1.17 \mathrm{vs}$. $1.99 \pm 0.92 \mathrm{I}, \mathrm{P}=0.016), \mathrm{MEF} 75$ by $22.9 \%$ $(-5.93 \pm 2.02$ vs. $-4.57 \pm 1.66 \mathrm{l} / \mathrm{s}, \mathrm{P}=0.036)$, FEF $75-85$ by $22.8 \%(-5.53 \pm 1.94$ vs. $-4.27 \pm 1.71 \mathrm{l} / \mathrm{s}$, $P=0.035), \mathrm{VC}$ by $17.5 \%(5.20 \pm 1.02$ vs. $4.29 \pm 1.17 \mathrm{l}$, $\mathrm{P}=0.019), \mathrm{IRV}$ by $30.0 \%(3.43 \pm 1.30 \mathrm{vs}$. $2.40 \pm 0.96, P=0.027), F V C$ by $15.2 \%(4.95 \pm 0.98$ vs. $4.20 \pm 1.21 \mathrm{I}, \mathrm{P}=0.045), \mathrm{FEV} 1$ by $14.9 \%$ $(4.37 \pm 0.83$ vs. $3.72 \pm 1.25 \mathrm{I}, \mathrm{P}=0.040), \mathrm{FEF} 75-85$ 
at $19.3 \%(141.97 \pm 38.03$ vs. $114.60 \pm 29.36 \%$, $\mathrm{P}=0.027$ ).

There is a tendency to the predominance of $\mathrm{VC}, \%$ $(P=0.052)$, FEVpef, \% ( $P=0.054), \operatorname{PEF}(P=0.064)$, MEF 50, I/s ( $P=0.052)$, MEF 75,\% ( $P=0.078)$, FEF 25-75, I/s ( $P=0.084)$, FEV2, I $(P=0.067)$, FEVpef, I $P=0.089)$, FEF $25-75,1 / s(P=0.073)$ in athletes, who developed the quality of strength, above similar indicators in athletes, who improved the quality of speed.

Thus, athletes who improved the quality of strength had a greater vital capacity of the lungs by $26.1 \%$ $(P=0.003)$, forced vital capacity of the lungs by $20.2 \%$ ( $P=0.016)$, due to the inspiratory reserve volume by $34.2 \%(P=0.008)$ than athletes, who improved the quality of speed. Also, strength athletes have higher indicators of the of forced expiratory volume 1 by $21.1 \%$ $(P=0.015)$, the forced expiratory volume to reach the peak expiratory flow by $30.2 \%(P=0.016)$, MEF 75 by $22.9 \%(P=0.036)$, FEF $75-85$ by $22.8 \%$ $(P=0.035)$ than in athletes, who developed the quality of speed, which indicates less resistance to air flow in the bronchi of small caliber in the expiratory phase.

Athletes, who improved endurance and speed, did not differ in terms of vital capacity, inspiratory reserve volume, respiratory volume, forced expiratory volume1, and were significantly less important, than athletes, who improved strength.

Since the athletes had probable statistical differences in terms of height and weight, we additionally performed calculations of volumetric indicators, namely RV, VC, IRV, ERV, taking into account the body mass index of athletes (Table 5).

It was found that the groups of athletes did not differ significantly in the indexed indicators of VC, RV and IRV, but strength athletes had slightly higher values of the index of IRV (113 $\pm 41 \mathrm{ml}$ vs. $102 \pm 40 \mathrm{ml}$ in athletes, who improved endurance and $94 \pm 35 \mathrm{ml}$ in athletes, who developed the quality of speed).

The analysis of index ERV, calculated from the body mass index of athletes, confirmed the pattern, that we obtained in the analysis of the absolute values of ERV. The lowest values of index ERV were found in strength athletes, compared with similar indicators in athletes, who improved the quality of endurance or speed.

\section{Discussion}

There are increased requirements to the respiratory system of athletes engaged in sports with the predominant manifestation of endurance. While training, the need for increased ventilation increases, but the maximum airflow, lung volume and contractility of the respiratory muscles show little changes, and in some cases there is even some restriction of airflow. A number of studies have suggested, that the functional capabilities of the respiratory system of highly skilled athletes lag behind the adapted to intense muscular activity capabilities of the cardiovascular system and neuromuscular system [13].

Increased susceptibility to bronchospasm in endurance athletes is described by many authors, referring to it as "exercise asthma". The results of the study [1] showed, that in three biathletes the rate of $\mathrm{FVCL}, \%$ was below
Table 3. Indicators of the external respiration function in athletes, who developed the quality of endurance or speed, $M \pm S D, M e\left(Q_{25} ; Q_{75}\right)$

\begin{tabular}{|c|c|c|c|c|}
\hline \multirow{2}{*}{$\begin{array}{l}\text { Value, } \\
\text { units of measure }\end{array}$} & \multicolumn{2}{|l|}{ Quality } & \multirow[t]{2}{*}{ P-level } & \multirow[t]{2}{*}{$\Delta \%$} \\
\hline & Endurance $(n=54)$ & Speed $(n=10)$ & & \\
\hline $\mathrm{RV}, \mathrm{I}$ & $0.69(0.53 ; 0.91)$ & $0.91(0.61 ; 1.21)$ & 0.385 & \\
\hline $\mathrm{RV}, \%$ & $93(73 ; 126)$ & $97(83 ; 194)$ & 0.255 & \\
\hline LVV, I & $13.29 \pm 4.93$ & $14.33 \pm 6.54$ & 0.746 & \\
\hline LVV, \% & $102.52 \pm 36.93$ & $123.90 \pm 56.81$ & 0.350 & \\
\hline $\mathrm{RR}, 1 / \mathrm{min}$ & $17.72 \pm 4.92$ & $17.12 \pm 3.81$ & 0.890 & \\
\hline$D_{\text {insp }}, S$ & $1.72 \pm 0.59$ & $1.60 \pm 0.55$ & 0.494 & \\
\hline$D_{\text {exp }}, S$ & $1.92 \pm 0.69$ & $2.07 \pm 0.61$ & 0.448 & \\
\hline$D_{\text {insp }} / D_{\text {exp }}$ & $0.94 \pm 0.37$ & $0.81 \pm 0.28$ & 0.271 & \\
\hline $\mathrm{RVm}, \mathrm{I}$ & $1.19 \pm 0.56$ & $0.97 \pm 0.40$ & 0.306 & \\
\hline $\mathrm{RRm}, \mathrm{l} / \mathrm{min}$ & $113.34 \pm 41.77$ & $111.38 \pm 42.75$ & 0.441 & \\
\hline $\mathrm{MVV}, \mathrm{l} / \mathrm{min}$ & $117.97 \pm 36.59$ & $107.19 \pm 25.59$ & 0.370 & \\
\hline MVV, \% & $91.37 \pm 25.52$ & $92.50 \pm 21.79$ & 0.823 & \\
\hline VC, I & $4.61 \pm 1.29$ & $4.03 \pm 0.92$ & 0.094 & \\
\hline VC, $\%$ & $89.70 \pm 23.35$ & $81.00 \pm 28.51$ & 0.566 & \\
\hline IRV, I & $2.14 \pm 0.86$ & $2.00 \pm 0.80$ & 0.394 & \\
\hline ERV, I & $1.65 \pm 0.94$ & $1.18 \pm 0.41$ & 0.044 & $28.5 \%$ \\
\hline $\mathrm{FVC}, \mathrm{I}$ & $4.83 \pm 1.12$ & $4.11 \pm 1.19$ & 0.031 & $14.9 \%$ \\
\hline FVC, \% & $92.34 \pm 15.93$ & $90.51 \pm 9.90$ & 0.846 & \\
\hline FEV1, I & $4.50 \pm 1.00$ & $3.88 \pm 1.06$ & 0.069 & \\
\hline FEV1, \% & $94.52 \pm 21.86$ & $91.70 \pm 11.36$ & 0.725 & \\
\hline FEVpef, I & $2.47 \pm 0.97$ & $1.99 \pm 0.92$ & 0.025 & $19.4 \%$ \\
\hline FEVpef, \% & $102.98 \pm 37.57$ & $89.40 \pm 34.55$ & 0.180 & \\
\hline IT, $\%$, value & $97.60(86.15 ; 111.50)$ & $100.55(78.70 ; 108.00)$ & 0.586 & \\
\hline IT, \% & $108.50(55.50 ; 124.50)$ & $111.50(87.00 ; 121.00)$ & 0.818 & \\
\hline FEV1/FVC, \%, value & $95.36 \pm 8.05$ & $93.59 \pm 8.57$ & 0.389 & \\
\hline FEV1/FVC, \% & $103.81 \pm 8.85$ & $102.01 \pm 9.31$ & 0.571 & \\
\hline PEF, I/s & $-5.93 \pm 1.73$ & $-5.14 \pm 1.59$ & 0.212 & \\
\hline PEF, \% & $74.30 \pm 20.14$ & $69.60 \pm 16.74$ & 0.677 & \\
\hline MEF $25,1 / s$ & $-4.91 \pm 1.84$ & $-4.61 \pm 1.42$ & 0.677 & \\
\hline MEF $25, \%$ & $67.48 \pm 24.79$ & $69.60 \pm 17.50$ & 0.637 & \\
\hline MEF 50, $1 / \mathrm{s}$ & $-5.62 \pm 1.62$ & $-4.82 \pm 1.50$ & 0.142 & \\
\hline MEF $50, \%$ & $70.72 \pm 18.73$ & $65.40 \pm 15.36$ & 0,644 & \\
\hline MEF 75, $1 / \mathrm{s}$ & $-5.33 \pm 1.78$ & $-4.57 \pm 1.66$ & 0.174 & \\
\hline MEF $75, \%$ & $80.06 \pm 22.89$ & $72.20 \pm 23.29$ & 0.421 & \\
\hline FEF $25-75,1 / \mathrm{s}$ & $-5.41 \pm 1.60$ & $-4.76 \pm 1.47$ & 0.284 & \\
\hline FEF $75-85,1 / s$ & $-5.03 \pm 1.57$ & $-4.27 \pm 1.71$ & 0.129 & \\
\hline Tpef, s & $0.44 \pm 0.19$ & $0.55 \pm 0.13$ & 0.774 & \\
\hline VC, I & $4.84 \pm 1.07$ & $4.29 \pm 1.17$ & 0.171 & \\
\hline VC, \% & $94.48 \pm 14.60$ & $92.60 \pm 10.01$ & 0.723 & \\
\hline IRV, I & $2.66 \pm 1.12$ & $2.40 \pm 0.96$ & 0.049 & $9.8 \%$ \\
\hline ERV, I & $1.35 \pm 1.08$ & $1.04 \pm 0.44$ & 0.727 & \\
\hline FVC, I & $4.71 \pm 0.99$ & $4.20 \pm 1.21$ & 0.037 & $10.8 \%$ \\
\hline FVC, \% & $91.62 \pm 12.30$ & $91.00 \pm 7.76$ & 0.262 & \\
\hline FEV0,5, I & $2.90 \pm 0.63$ & $2.60 \pm 0.91$ & 0.875 & \\
\hline FEV1, I & $4.26 \pm 0.85$ & $3.72 \pm 1.25$ & 0.875 & \\
\hline FEV1, \% & $98.51 \pm 17.60$ & $96.41 \pm 15.85$ & 0.745 & \\
\hline FEV2, I & $4.80(3.94 ; 5.36)$ & $4.00(3.37 ; 4.56)$ & 0.969 & \\
\hline FEV2, \% & $96.33 \pm 24.91$ & $96.25 \pm 8.81$ & 0.909 & \\
\hline FEV3, I & $5.53 \pm 0.89$ & $4.29 \pm 1.32$ & 0.688 & \\
\hline FEV3, \% & $88.69 \pm 42.91$ & $93.00 \pm 8.54$ & 0.977 & \\
\hline FEVpef, I & $1.12 \pm 0.42$ & $0.94 \pm 0.43$ & 0.262 & \\
\hline FEVpef, \% & $109.78 \pm 42.15$ & $106.25 \pm 34.77$ & 0.223 & \\
\hline IT & $91.86(81.30 ; 107.00)$ & $95.65(83.10 ; 103.00)$ & 0.966 & \\
\hline IT, \%, value & $89.79 \pm 12.61$ & $86.96 \pm 11.14$ & 0.916 & \\
\hline IT, \% & $107.24 \pm 12.83$ & $104.10 \pm 14.53$ & 0.579 & \\
\hline FIV1/FVC, \%, value & $91.03 \pm 7.91$ & $88.94 \pm 10.62$ & 0.010 & $2.3 \%$ \\
\hline FIV1/FVC, \% & $110.15 \pm 9.81$ & $106.30 \pm 13.81$ & 0.875 & \\
\hline FIV2/FVC, \%, value & $99.55 \pm 1.11$ & $99.23 \pm 1.17$ & 0.134 & \\
\hline FIV2/ FVC, \% & $105.29 \pm 1.36$ & $105.25 \pm 1.16$ & 0.858 & \\
\hline
\end{tabular}




\section{Cont. of Table 3.}

\begin{tabular}{|c|c|c|c|c|}
\hline \multirow{2}{*}{$\begin{array}{l}\text { Value, } \\
\text { units of measure }\end{array}$} & \multicolumn{2}{|l|}{ Quality } & \multirow[t]{2}{*}{ P-level } & \multirow[t]{2}{*}{$\Delta \%$} \\
\hline & Endurance $(n=54)$ & Speed $(n=10)$ & & \\
\hline FIV3/FVC, $\%$, value & $100.00 \pm 0.20$ & $99.90 \pm 0.22$ & 0.688 & \\
\hline FIV3/FVC, \% & $103.00 \pm 0.20$ & $103.00 \pm 0.20$ & 0.999 & \\
\hline PEF/FEVpef, I/s & $6.15(4.48 ; 8.83)$ & $6.90(5.18 ; 8.11)$ & 0.800 & \\
\hline FEVpef, I/s & $6.75 \pm 1.71$ & $6.19 \pm 2.27$ & 0.397 & \\
\hline FEVpef, \% & $75.64 \pm 17.67$ & $76.40 \pm 20.17$ & 0.799 & \\
\hline MEF $25, \mathrm{l} / \mathrm{s}$ & $6.33 \pm 1.61$ & $6.01 \pm 2.14$ & 0.554 & \\
\hline MEF $25, \%$ & $78.08 \pm 18.71$ & $81.00 \pm 21.45$ & 0.457 & \\
\hline MEF $50,1 / \mathrm{s}$ & $5.20 \pm 1.27$ & $4.65 \pm 1.61$ & 0.208 & \\
\hline MEF $50, \%$ & $98.36 \pm 20.89$ & $94.00 \pm 22.96$ & 0.821 & \\
\hline MEF $75,1 / \mathrm{s}$ & $3.37 \pm 1.02$ & $2.85 \pm 1.04$ & 0.080 & \\
\hline MEF $75, \%$ & $125.55 \pm 33.34$ & $112.50 \pm 29.08$ & 0.310 & \\
\hline FEF $0.2-1.2,1 / \mathrm{s}$ & $4.35 \pm 2.09$ & $4.02 \pm 1.59$ & 0.693 & \\
\hline FEF $25-75, \mathrm{l} / \mathrm{s}$ & $4.81 \pm 1.15$ & $4.31 \pm 1.48$ & 0.194 & \\
\hline FEF $25-75, \%$ & $101.27 \pm 25.85$ & $97.00 \pm 22.98$ & 0.742 & \\
\hline FEF $75-85,1 / s$ & $2.94 \pm 0.95$ & $2.40 \pm 0.91$ & 0.060 & \\
\hline FEF $75-85, \%$ & $138.66 \pm 40.13$ & $114.60 \pm 29.36$ & 0.092 & \\
\hline
\end{tabular}

Table 4. Indicators of the external respiration function in athletes, who developed the quality of strength or speed, $M \pm S D, M e\left(Q_{25} ; Q_{75}\right)$

\begin{tabular}{|c|c|c|c|c|}
\hline \multirow{2}{*}{$\begin{array}{l}\text { Value, } \\
\text { units of measure }\end{array}$} & \multicolumn{2}{|l|}{ Quality } & \multirow[t]{2}{*}{ P-level } & \multirow[t]{2}{*}{$\Delta \%$} \\
\hline & Strength $(n=31)$ & Speed $(n=10)$ & & \\
\hline RV, I & $0.92(0.63 ; 1.34)$ & $0.91(0.61 ; 1.21)$ & 0.421 & \\
\hline $\mathrm{RV}, \%$ & $103(82 ; 156)$ & $97(83 ; 194)$ & 0.832 & \\
\hline LVV, I & $15.15 \pm 4.83$ & $14.33 \pm 6.54$ & 0.504 & \\
\hline LVV, \% & $111.16 \pm 40.31$ & $123.90 \pm 56.81$ & 0.585 & \\
\hline $\mathrm{RR}, \mathrm{I} / \mathrm{min}$ & $16.70 \pm 5.28$ & $17.12 \pm 3.81$ & 0.761 & \\
\hline$D_{\text {insp, }}, s$ & $1.66 \pm 0.52$ & $1.60 \pm 0.55$ & 0.606 & \\
\hline$D_{\text {exp }}, s$ & $2.31 \pm 0.97$ & $2.07 \pm 0.61$ & 0.606 & \\
\hline $\mathrm{D}_{\text {insp }} / \mathrm{D}_{\text {exp }}$ & $0.78 \pm 0.27$ & $0.81 \pm 0.28$ & 0.430 & \\
\hline $\mathrm{RVm}, \mathrm{I}$ & $1.23 \pm 0.58$ & $0.97 \pm 0.40$ & 0.274 & \\
\hline $\mathrm{RRm}, \mathrm{I} / \mathrm{min}$ & $109.19 \pm 35.10$ & $111.38 \pm 42.75$ & 0.485 & \\
\hline $\mathrm{MVV}, \mathrm{l} / \mathrm{min}$ & $120.36 \pm 39.98$ & $107.19 \pm 25.59$ & 0.347 & \\
\hline MVV, \% & $86.65 \pm 21.56$ & $92.50 \pm 21.79$ & 0.387 & \\
\hline VC, I & $5.45 \pm 1.31$ & $4.03 \pm 0.92$ & 0.003 & $26.1 \%$ \\
\hline VC, \% & $99.14 \pm 20.94$ & $81.00 \pm 28.51$ & 0.052 & \\
\hline IRV, I & $3.04 \pm 1.15$ & $2.00 \pm 0.80$ & 0.008 & $34.2 \%$ \\
\hline ERV, I & $1.28 \pm 0.55$ & $1.18 \pm 0.41$ & 0,346 & \\
\hline FVC, I & $5.15 \pm 1.17$ & $4.11 \pm 1.19$ & 0,016 & $20,2 \%$ \\
\hline FVC, \% & $95.84 \pm 17.69$ & $90.51 \pm 9.90$ & 0.301 & \\
\hline FEV1, I & $4.92 \pm 1.23$ & $3.88 \pm 1.06$ & 0.015 & $21.1 \%$ \\
\hline FEV1, \% & $99.26 \pm 18.84$ & $91.70 \pm 11.36$ & 0.202 & \\
\hline FEVpef, I & $2.85 \pm 1.17$ & $1.99 \pm 0.92$ & 0.016 & $30.2 \%$ \\
\hline FEVpef, \% & $118.32 \pm 47.64$ & $89.40 \pm 34.55$ & 0.054 & \\
\hline $\mathrm{IT}, \%$, value & $93.10 \pm 14.13$ & $96.48 \pm 14.60$ & 0.431 & \\
\hline $\mathrm{IT}, \%$ & $105.00(93.00 ; 112.00)$ & $111.50(87.00 ; 121.00)$ & 0.326 & \\
\hline FEV1/FVC, \%, value & $95.46 \pm 7.49$ & $93.59 \pm 8.57$ & 0.478 & \\
\hline FEV1/FVC, \% & $103.90 \pm 8.32$ & $102.01 \pm 9.31$ & 0.671 & \\
\hline PEF, I/s & $-6.63 \pm 2.14$ & $-5.14 \pm 1.59$ & 0.064 & \\
\hline PEF, \% & $79.29 \pm 20.62$ & $69.60 \pm 16.74$ & 0.230 & \\
\hline MEF $25,1 / s$ & $-5.59 \pm 2.07$ & $-4.61 \pm 1.42$ & 0.255 & \\
\hline MEF $25, \%$ & $72.29 \pm 21.48$ & $69.60 \pm 17.50$ & 0.898 & \\
\hline MEF $50,1 / s$ & $-6.22 \pm 1.98$ & $-4,82 \pm 1,50$ & 0.052 & \\
\hline MEF $50, \%$ & $74.94 \pm 18.68$ & $65.40 \pm 15.36$ & 0.224 & \\
\hline MEF $75,1 / \mathrm{s}$ & $-5.93 \pm 2.02$ & $-4.57 \pm 1.66$ & 0.036 & $22.9 \%$ \\
\hline MEF $75, \%$ & $90.84 \pm 27.56$ & $72.20 \pm 23.29$ & 0.078 & \\
\hline FEF $25-75, \mathrm{l} / \mathrm{s}$ & $-6.06 \pm 2.03$ & $-4.76 \pm 1.47$ & 0.084 & \\
\hline FEF $75-85,1 / s$ & $-5.53 \pm 1.94$ & $-4.27 \pm 1.71$ & 0.035 & $22.8 \%$ \\
\hline Tpef, s & $0.46 \pm 0.20$ & $0.55 \pm 0.13$ & 0.715 & \\
\hline VC, I & $5.20 \pm 1.02$ & $4.29 \pm 1.17$ & 0.019 & $17.5 \%$ \\
\hline
\end{tabular}

$80 \%$. Five biathletes showed a decrease in FEV1, \%, which characterizes the total capacity of the bronchial tree. Six biathletes had a reduced Tiffeneau index, which is also a sensitive index of airway obstruction. The authors received a decrease in the velocity characteristics of pulmonary ventilation in female athletes. Five biathletes had a reduced peak expiratory flow (PEF, \%) -the maximum value of the flow, achieved during respiration. Decreased MEF indicates the presence of obstructive changes in lungs, while a decrease in MEF 75, \% indicates obstruction in the small bronchi, MEF 50, \% - obstruction at the level of the middle bronchi, MEF 25, \% - obstruction of the large bronchi. Obstruction at the level of small and large bronchi was observed in four of the examined biathletes, in eight - at the level of the middle bronchi [1]. This decrease in bronchial patency in biathletes allowed authors to conclude, that the area of the functioning surface of the alveolar-capillary membranes is reduced, the volume of blood flow in the capillary bed of the lungs is reduced and the use of oxygen in ventilated air is reduced. Researchers have suggested, that an inadequate ratio of alveolar ventilation and perfusion may, in turn, lead to a significant reduction in arterial blood oxygen saturation and the development of arterial hypoxemia, which will significantly limit the aerobic performance of athletes [1].

Govorukhina O. A. and co-authors [4] found, that the volume of pulmonary ventilation of athletes, engaged in cross-country skiing and swimming, significantly superior to athletes, engaged in biathlon. According to the authors, such results reflect the specificity of training loads in certain sports of cyclic structure. Girls and boys, competing in cross-country skiing also had the highest rates of pulmonary ventilation, which indicates the superiority of the strength of the expiratory muscles and the patency of the bronchial tree in relation to athletes of other specialties. The lowest values of the speed of pulmonary ventilation were found in girls and boys, who were engaged in swimming. Analysis of the speed of pulmonary ventilation of cyclic sports athletes allowed the authors to conclude, that the expiratory muscles of the athletes under study are well developed, and there are no violations of the patency of the bronchial tree. At the same time the most powerful exhalations were able to perform athletes, engaged in cross-country skiing. The lowest airflow velocities and, accordingly, the largest duration of exhalation were found in the group of swimmers. Such results may be due to the specifics of the environment, in which swimmers perform the bulk of training work. During swimming, the human body is in the water, which puts constant pressure on the chest and, accordingly, facilitates the work of the muscles responsible for the act of exhalation [4].

In our study, we found no evidence of airway obstruction in athletes, who improved endurance or strength or speed. Athletes, who developed mostly endurance quality as opposed to strength athletes and athletes, who improved speed quality, were likely to have a greater reserve expiratory volume. Athletes, who improved mainly strength quality had greater lung capacity, respiratory volume, inspiratory reserve volume, and expiratory velocity (FEV1, MEF 75, FEF 75-85), than athletes, who developed mostly endurance or speed qualities. 
At the same time E. A. Baranova and L. V. Kapilevich [2] received in the group of athletes after exercise a decrease in bronchial patency at the level of the large bronchi, as evidenced by a decrease in PEF and MEF 25 , as well as the Tiffeneau index. The mechanisms of this phenomenon are not fully clear. Possibly, physical exercise in athletes no longer plays the role of a powerful stressor, the release of adrenaline during exercise is not so significant, which leads to increased tone of the smooth muscles of the bronchi. From the point of view of respiratory mechanics, the decrease in bronchial patency, according to the authors, may be associated with the effect of ejection, i.e. with a decrease in pressure on the bronchial wall with increasing air flow rate due to increased respiratory muscle activity. At the same time, more efficient work of respiratory muscles in athletes is reflected in the increase of MEF 75 and MEF 85. These indicators reflect the condition of the small bronchi, which largely depend on muscular effort. Probably, this mechanism in athletes compensates for the factor of narrowing of the large bronchi.

Thus, training in cyclic sports forms a number of factors, some of which adversely affect pulmonary ventilation and limit the capabilities of the cardio-respiratory system. At the same time, there is a formation of mechanisms, that compensate for these negative effects and allow to meet the body's need for oxygen at the peak of exercise. Thus, after exercise in athletes there is a decrease in air flow rate at the level of the large bronchi, which is compensated by an increase in bronchial patency at the level of medium and small bronchi. The latter is provided primarily by the efforts of the respiratory muscles [2].

Of course, one of the limiting components of the effectiveness of the external respiratory system are the respiratory muscles, which in the process of inspiration carry out work to overcome the elastic and inelastic resistance [10]. In work of respiratory muscles of athletes there is a pattern, the stronger the respiratory muscles are, the more efficient the ventilation is, which in its turn determines the level of overall physical endurance and efficiency of athletes [3]. A number of studies have shown, that trained people have certain features of pulmonary ventilation parameters. For example, young rowers had higher lung capacity, forced lung capacity, and respiratory volume, than non-athletic peers [1]. Baranova E. A. and Kapilevich L.V. stated, that in the study of 1-2 degree athletes, engaged in cyclic sports, and students, who did not go in for sports, lung ventilation of highly trained students was characterized by a decrease in inelastic resistance of the respiratory muscles [2].

The question of possibility to achieve a higher level of physical endurance by training the muscles of breath, requires further study. Shamsutdinova M. E. and coauthors found, that the presence of initial features of lung ventilation parameters in men is not a prerequisite for the formation of a high level of endurance and performance, which are observed in professional athletes, and are formed during sports training [11].

Presented by S. O. Kryukov and co-authors analysis [7] of ventilatory reactions of young wrestlers aged 12-13 years during exercise, showed, that the limiting factor in the aerobic capacity of adolescents is a change in

\section{Cont. of Table 4.}

\begin{tabular}{|c|c|c|c|c|}
\hline \multirow{2}{*}{$\begin{array}{l}\text { Value, } \\
\text { units of measure }\end{array}$} & \multicolumn{2}{|l|}{ Quality } & \multirow[t]{2}{*}{ P-level } & \multirow[t]{2}{*}{$\Delta \%$} \\
\hline & Strength $(n=31)$ & Speed $(n=10)$ & & \\
\hline VC, \% & $95.23 \pm 11.17$ & $92.60 \pm 10.01$ & 0.553 & \\
\hline IRV, I & $3.43 \pm 1.30$ & $2.40 \pm 0.96$ & 0.027 & $30.0 \%$ \\
\hline ERV, I & $0.79 \pm 0.82$ & $1.04 \pm 0.44$ & 0.439 & \\
\hline FVC, I & $4.95 \pm 0.98$ & $4.20 \pm 1.21$ & 0.045 & $15.2 \%$ \\
\hline FVC, \% & $91.81 \pm 9.95$ & $91.00 \pm 7.76$ & 0.855 & \\
\hline FEV0.5, I & $2.97 \pm 0.66$ & $2.60 \pm 0.91$ & 0.125 & \\
\hline FEV1, I & $4.37 \pm 0.83$ & $3.72 \pm 1.25$ & 0.040 & $14.9 \%$ \\
\hline FEV1, \% & $99.45 \pm 11.89$ & $96.41 \pm 15.85$ & 0.671 & \\
\hline FEV2, I & $4.97 \pm 0.93$ & $4.28 \pm 1.21$ & 0.067 & \\
\hline FEV2, \% & $94.62 \pm 9.04$ & $96.25 \pm 8.81$ & 0.660 & \\
\hline FEV3, I & $5.34(4.51 ; 6.14)$ & $4.14(3.18 ; 4.71)$ & 0.463 & \\
\hline FEV3, \% & $91.34 \pm 7.18$ & $93.00 \pm 8.54$ & 0.916 & \\
\hline FEVpef, I & $1.14 \pm 0.49$ & $0.94 \pm 0.43$ & 0.089 & \\
\hline FEVpef, \% & $108.92 \pm 50.48$ & $106.25 \pm 34.77$ & 0.884 & \\
\hline IT & $84.05 \pm 18.07$ & $92.31 \pm 16.19$ & 0.165 & \\
\hline IT, \%, value & $84.41 \pm 13.29$ & $86.96 \pm 11.14$ & 0.522 & \\
\hline $\mathrm{IT}, \%$ & $105.53 \pm 15.80$ & $104.10 \pm 14.53$ & 0.815 & \\
\hline FIV1/FVC, $\%$, value & $88.80 \pm 9.76$ & $88.94 \pm 10.62$ & 0.820 & \\
\hline FIV1/FVC, \% & $109.62 \pm 11.73$ & $106.30 \pm 13.81$ & 0.465 & \\
\hline FIV2/FVC, $\%$, value & $98.98 \pm 2.16$ & $99.23 \pm 1.17$ & 0.912 & \\
\hline FIV2/ FVC, \% & $104.72 \pm 2.64$ & $105.25 \pm 1.16$ & 0.977 & \\
\hline FIV3/FVC, \%, value & $99.89 \pm 0.29$ & $99.90 \pm 0.22$ & 0.874 & \\
\hline FIV3/FVC, \% & $102.91 \pm 0.30$ & $103.00 \pm 0.20$ & 0.500 & \\
\hline PEF/FEVpef, I/s & $6.87(4.05 ; 10.20)$ & $6.90(5.18 ; 8.11)$ & 0.903 & \\
\hline FEVpef, I/s & $7.09 \pm 2.22$ & $6.19 \pm 2.27$ & 0.347 & \\
\hline FEVpef, \% & $75.32 \pm 18.82$ & $76.40 \pm 20.17$ & 0.704 & \\
\hline MEF $25,1 / s$ & $6.49 \pm 2.09$ & $6.01 \pm 2.14$ & 0.495 & \\
\hline MEF $25, \%$ & $75.71 \pm 20.38$ & $81.00 \pm 21.45$ & 0.378 & \\
\hline MEF $50,1 / s$ & $5.36 \pm 1.25$ & $4.65 \pm 1.61$ & 0.114 & \\
\hline MEF $50, \%$ & $97.88 \pm 19.69$ & $94.00 \pm 22.96$ & 0.988 & \\
\hline MEF $75,1 / s$ & $3.32 \pm 0.93$ & $2.85 \pm 1.04$ & 0.104 & \\
\hline MEF $75, \%$ & $128.39 \pm 33.22$ & $112.50 \pm 29.08$ & 0.111 & \\
\hline FEF $0.2-1.2,1 / \mathrm{s}$ & $4.60 \pm 2.63$ & $4.02 \pm 1.59$ & 0.553 & \\
\hline FEF $25-75,1 / s$ & $4.94 \pm 1.14$ & $4.31 \pm 1.48$ & 0.073 & \\
\hline FEF $25-75, \%$ & $102.29 \pm 20.22$ & $97.00 \pm 22.98$ & 0.606 & \\
\hline FEF $75-85,1 / s$ & $2.83 \pm 0.86$ & $2.40 \pm 0.91$ & 0.141 & \\
\hline FEF 75-85, \% & $141.97 \pm 38.03$ & $114.60 \pm 29.36$ & 0.027 & $19.3 \%$ \\
\hline
\end{tabular}

Table 5. Indexed indicators of RV, VC, IRV and ERV in athletes, who improved the quality of endurance, strength or speed, $M \pm S D$

\begin{tabular}{l|l|l|l|l|l|l}
\hline $\begin{array}{l}\text { Value, units } \\
\text { of measure }\end{array}$ & Endurance & Strength & Speed & $\mathbf{P}_{1-2}$ & $\mathbf{P}_{1-3}$ & $\mathbf{P}_{2-3}$ \\
$\begin{array}{l}\text { Index RV, } \\
\text { I } \times \mathrm{m}^{2} / \mathrm{kg}\end{array}$ & $0.036 \pm 0.017$ & $0.040 \pm 0.020$ & $0.040 \pm 0.016$ & 0.379 & 0.531 & 0.962 \\
$\begin{array}{l}\text { Index IRV, } \\
\text { I } \times \mathrm{m}^{2} / \mathrm{kg}\end{array}$ & $0.102 \pm 0.040$ & $0.113 \pm 0.041$ & $0.094 \pm 0.035$ & 0.234 & 0.556 & 0.193 \\
$\begin{array}{l}\text { Index ERV, } \\
\text { I } \times \mathrm{m}^{2} / \mathrm{kg}\end{array}$ & $0.084 \pm 0.037$ & $0.052 \pm 0.023$ & $0.055 \pm 0.019$ & 0.00003 & 0.009 & 0.809 \\
$\begin{array}{l}\text { Index VC, } \\
\text { I } \times \mathrm{m}^{2} / \mathrm{kg}\end{array}$ & $0.225 \pm 0.054$ & $0.205 \pm 0.062$ & $0.189 \pm 0.037$ & 0.132 & 0.067 & 0.426 \\
\hline
\end{tabular}

the structure of vital capacity of the lungs in the direction of a significant reduction in expiratory reserve.

In our study, we also noted, that athletes who developed strength quality had a greater vital lungs capacity, due to the predominance of respiratory volume and reserve inspiratory volume, but less expiratory reserve, than athletes, who improved quality of endurance. 
In the study of S. O. Kryukov and co-authors [7] in wrestlers a discrepancy between the increasing volume of pulmonary ventilation and bronchial patency was found. The increase in ventilation was mainly due to an increase in respiratory rate to $40.9 \pm 3.07$ cycles $/ \mathrm{min}(P<0.01)$ and, to a lesser extent, due to an increase in respiratory volume, which increased by an average of $600.0 \mathrm{ml}(P<0.01)$. Manifestation of such an ineffective ventilatory response was facilitated by a decrease in vital capacity of the lungs from $2.45 \pm 0.12 \mathrm{I}$ at rest to $1.80 \pm 0.12 \mathrm{I}$ at the end of physical activity $(P<0.001)$. Analysis of the fractional components of VC showed, that the decrease in vital capacity of the lungs during exercise was influenced by both the inspiratory reserve volume and expiratory reserve volume. The ERV decreased more significantly, which decreased to $70.00 \pm 2.96 \mathrm{ml}(\mathrm{P}<0.001)$. The formation of the respiration pattern in these conditions was due to the increase of the frequency parameter in the growth of LVV, which is a factor in the manifestation of hyperventilation syndrome, which reduces the gas exchange capacity of the lungs. The reason for this phenomenon, the authors believe, is an insufficiency of the respiratory muscles, especially the expiratory muscles, the weakness of which helped to restrain the increase in alveolar ventilation [7].

One of the leading components of the ventilatory function of the lungs is the functionality of the tracheobronchial tree. As the volume of air flowing through the lungs increases, bronchial patency should also increase. However, S. O. Kryukov and co-authors [7] revealed some stabilization of the volumetric expiratory rate in the large, medium and small bronchi at the last stage of stress testing, relative to the previous load. The average expiratory rate also did not change (FEF 25-75). That is, the strengthening of ventilatory function was not accompanied by an adequate increase in airway patency. Among the reasons, that reduce the functionality of airways, the authors attributed the decrease in radially directed pressure, which restrains the collapse of the bronchi. Increasing in respiratory movements frequency contributes to its reduction, which may result in a decrease in bronchial patency during forced breathing. In addition, adolescents are characterized by regional differences in the mechanical properties of the lungs and regional differences in intra-pleural pressure, which creates the conditions for a nonlinear distribution of lung ventilation. These features of the formation of the ventilatory response to exercise can reduce performance, restrain the metabolic demand of the body [7].

The functional state of the external respiratory system is closely related to the nature of metabolic reactions. Increased or decreased metabolism is reflected in the production of carbon dioxide, causing certain changes in gas exchange. The dynamics of $\mathrm{CO}_{2}$ release with gradually increasing loads in aerobic mode changes as follows with increasing power, there is a progressive increase in $\mathrm{CO}_{2}$. In turn, the release of $\mathrm{CO}_{2}$ through lungs is directly dependent on the intensity of the load and vice versa - on the physical fitness of the athlete [12].

Oxygen utilization rate and oxygen effect indicator of the respiratory cycle, which objectively characterize the reserves of the respiratory system, which reflects the energy value of pulmonary ventilation, depend on the level of tissue metabolism, pulmonary ventilation and lung diffusion capacity.

Reserve capacity of the external respiration system largely depends not only on the orientation, but also on the period of the training process. The obtained data on the seasonal dynamics of the ratio of the response of external respiration and hemodynamics during exercise, allowed V. L. Karpman and co-authors [6] to identify a significant decrease in the values of the ratio $\triangle \mathrm{LVV} / \triangle \mathrm{MBV}$ and the integrated efficiency of the system in athletes during summer period, which indicates higher reserve capabilities of the cardiorespiratory system at the beginning of the competitive period. This is indicated, first of all, by the signs of increasing the role of volumetric characteristics of external respiration and hemodynamics in the reactions of the cardio-respiratory system during exercise, changes in the connection of external respiratory and circulatory reactions mainly due to reduced minute pulmonary ventilation [6].

Thus, the ability to deliver sufficient oxygen and release the body from excess carbon dioxide during intensive work is determined by airway patency, lung function and the level of development of the chest muscles, that provide ventilation. The high requirements for the external respiratory system of athletes are the key to the effective work of the entire cardio-respiratory system.

\section{Conclusions}

1. Athletes, who have developed a quality of strength have a greater vital capacity of the lungs, due to the predominance of respiratory volume and inspiratory reserve volume, but less expiratory reserve volume, than in athletes, who improved the quality of endurance.

2. Athletes, who developed endurance quality, in contrast to athletes, who improved the quality of speed, have a higher forced vital capacity of the lungs, due to the predominance of inspiratory and expiratory reserve volumes.

3. The function of external respiration of athletes, who improved the quality of speed is characterized by lower vital capacity of the lungs, forced vital capacity of the lungs, due to reduced inspiratory reserve volume, and greater resistance to airflow in the bronchi of small caliber in the expiratory phase, than in athletes, who developed the quality of strength.

Prospects for further research are to elucidate the features of the functional state of the external respiratory system of athletes, taking into account the polymorphism of the genes NOS, VEGFA, ACE.

Conflict of interest: authors have no conflict of interest to declare. Конфмікт інтересів: віАсутній.

Надійшка Ао редакції / Received: 26.08.2020

Після Аоопрацювання / Revised: 19.01.2021

Прийнято Ао Аруку / Accepted: 02.02.2021

Information about authors:

Kanyhina S. M., MD, PhD, Associate Professor of the Department of Physical Rehabilitation, Sports Medicine, Physical Education and Health, Zaporizhzhia State Medical University, Ukraine. ORCID ID: 0000-0002-8197-299X 
Potapenko M. S., MD, PhD, Assistant of the Department of Anesthesiology and Intensive Care, Zaporizhzhia State Medical University, Ukraine.

Kurilets L. O., MD, PhD, Assistant of the Department of Propaedeutic of Internal Medicine, Radiation Diagnostics and Radiation Treatment, Zaporizhzhia State Medical University, Ukraine.

\section{Відомості про авторів:}

Канигіна С. М., канА. меА. наук, Аоцент каф. фізичної реабімітації, спортивної меАицини, фізичного виховання зАоров'я, Запорізький Аержавний медичний університет, Україна.

Потапенко М. С., канА. меА. наук, асистент каф. анестезіологіі та інтенсивної терапії, Запорізький Аержавний меАичний університет, Україна.

Курілець А. О., канА. меА. наук, асистент каф. пропедевтики внутрішньої медицини, променевої діагностики та променевої терапії, Запорізький Аержавний меАичний університет, Україна.

\section{Сведения 06 авторах:}

Каныгина С. Н., канд. меА. наук, Аоцент каф. физической реабилитации, спортивной медицины, физического воспитания и зАоровья, Запорожский государственный меАицинский университет, Украина.

Потапенко М. С., канА. меА. наук, Аоцент каф. анестезиологии и интенсивной терапии, Запорожский государственный меАицинский университет, Украина.

Курилец ^. О., канА. меА. наук, ассистент каф. пропедевтики внутренней медицины, лучевой Аиагностики и мучевой терапии, Запорожский госуАарственный меАицинский университет, Украина.

\section{References}

[1] Aikin, V. A., Reutskaya, E. A., \& Sukhachov, E. A. (2015). Funktsional'noe sostoyanie dykhatel'noi sistemy biatlonistok vysokoi kvalifikatsii [Functional state of respiratory system of the elite female biathletes]. Uchenye zapiski universiteta im. P. F. Lesgafta, (12), 14-19. [in Russian].

[2] Baranova, E.A. \& Kapilevich, L. V. (2013). Vliyanie fizicheskoi nagruzki na pokazateli legochnoi ventilyatsii u sportsmenov [The influence of physical activity on the indicators of pulmonary ventilation in athletes]. Vestnik Tomskogo gosudarstvennogo universiteta, (374), 152-155. [in Russian].

[3] Volkov, N. I., \& Oleinikov, V. I. (2011). Bioenergetika sporta [Sports bioenergy]. Sovetskii sport. [in Russian]

[4] Govorukhina, A. A. \& Vetkalova, N. S. (2018). Osobennosti adaptatsii sistemy vneshnego dykhaniya sportsmenov tsiklicheskikh vidov sporta, treniruyushchikhsya v KhMAO-Yugre [Features of adaptation of the external respiration system in athletes of cyclic sports training in the Khanty-Mansi Autonomous Area-Yugra]. Vestnik meditsinskogo instituta «REAVIZ», (1), 156-163. [in Russian].

[5] Isupov, I. B., Sevrukova, G. A., Shmarina, Ya. G., Ryaskova, K. A.. \& Belova, V. A. (2017). Ekspiratornye legochnye ob"emy molodykh lyudei $\checkmark$ usloviyakh pokoya i v period vosstanovleniya posle dozirovannoi fizicheskoi nagruzki [Expiratory Lung Volumes of Young People at Rest and Recovery Period after a Dosed Physical Load]. Izvestiya Saratovskogo universiteta. Novaya seriya. Seriya: Khimiya. Biologiya. Ekologiya, 17(2), 197-200. [in Russian]. https://doi.org/10.18500/18169775-2017-17-2-197-200

[6] Karpman, V. L., Belotserkovskii, Z. B., \& Gudkov, I. A. (1988). Testirovanie v sportivnoi meditsine [Testing in sports medicine]. Fizkul'tura i sport. [in Russian].

[7] Kryukov, S. A., Pogodin, S. V., \& Dildin, O. I. (2017). Osobennosti struktury ventilyatornoi reaktsii u bortsov 12-13 let pri rabote $v$ razlichnykh trenirovochnykh rezhimakh [Features of the structure of ventilation reaction at wrestlers 12-13 years at work in various training regimes]. Izvestiya Tul'skogo gosudarstvennogo universiteta. Fizicheskaya kul'tura. Sport, (2), 159-163. [in Russian].

[8] Polataiko, Yu. (2012). Vplyv fizychnoho navantazhennia maksymalnoi potuzhnosti na reaktyvnist kardiorespiratornoi systemy v sportsmeniv. [Influence of Physical Loads of Maximal Power on Reactivity of Cardiovascuiary System of Sportsmen] Fizychne vykhovannia, sport i kultura zdorovia u suchasnomu suspilstvi, (3), 367-371. [in Ukrainian].

[9] Struchkov, P. V. \& Vorob'eva, Z. V. (2005). Standarty vypolneniya i otsenki rezul'tatov issledovaniya vneshnego dykhaniya (na osnove rekomendatsii Evropeiskogo respiratornogo obshchestva i Amerikanskogo torakal'nogo obshchestva) [Standards for implementation and evaluation of the results of external respiration studies (based on the European Respiratory Society and the American Thoracic Society Guidelines)]. European Respiratory Journal, 26(2), 319-968. [in Russian].

[10] Suslina, I. V. (2012). Individual'no-tipologicheskie osobennosti funktsional'nykh vozmozhnostei dykhatel'noi muskulatury u sportsmenov [Dependence of breathing muscles functional abilities on spcific features of the organism]. Fundamental'nye issledovaniya, (9), 73-77. [in Russian].

[11] Shamsutdinova, M. E., \& Miroshnichenko, I. V. (2016). Osobennosti parametrov vneshnego dykhaniya u muzhchin s razlichnym urovnem fizicheskoi rabotosposobnosti i vynoslivosti [Features of external men respiration parameters with different levels of physical performance and stamina]. Vestnik Orenburgskogo gosudarstvennogo universiteta, (11), 75-79. [in Russian].

[12] Yashanin, Ya., Voynar, Yu., Yashanin, N., \& Skurvidas, A. (2002) Biologicheskie osnovy optimizatsii trenirovochnykh nagruzok [Biological basis for optimization of training loads]. Nauka v olimpiiskom sporte, (1), 54-59. [in Russian].

[13] Amann, M. (2012). Pulmonary system limitations to endurance exercise performance in humans. Experimental Physiology, 97(3), 311-318. https://doi.org/10.1113/expphysiol.2011.058800 